\title{
Contribution of Educational System Quality and Health Condition to Welcome Demographic Bonus in Indonesia
}

\author{
Hasna Ula Nur Azizah \\ Graduate School \\ Universitas Negeri Yogyakarta \\ Yogyakarta, Indonesia \\ hasnaula2.2017@student.uny.ac.id
}

\author{
Setyabudi Indartono \\ Graduate School \\ Universitas Negeri Yogyakarta \\ Yogyakarta, Indonesia \\ setyabudi_indartono@uny.ac.id
}

\begin{abstract}
Demographic transition that occurs in the last decade in Indonesia will open opportunities for it to be able to achieve demographic bonus in 2020-2030. At that time, the number of productive age population is twice higher the non-productive one. This must be utilized as affective as possible because it will only happen once, and it can be realized if the productive age population can really work productively. So, it is expected that this demographic bonus can really boost Indonesia's economic sectors in the future. However, on the other hand, Indonesia is currently facing serious problems about education and health. Education and health are still not evenly distributed throughout the regions of the country. With high work productivity, it is possible to achieve high quality of education and health, and Indonesia can strengthen its influence at both regional and international levels. But the demographic bonus can become a threat if it is not managed properly and we do not yet have good human resource investment.
\end{abstract}

Keywords - demography, demographic bonus, education, health

\section{INTRODUCTION}

The success of the family planning program (KB) for decades has been able to shift the population under the age of 15 years (children and adolescents) who were initially large at the bottom of the Indonesian population pyramid to the older (productive ages of 15-64) people. The pyramid structure that bulges in the middle is somehow advantageous, because the burden of economic dependence or support that must be provided by the productive age population for the children age (under 15 years) and old one (over 64 years) becomes lighter. Meanwhile, the recent results of 2010 census also show a positive trend, where the population of productive age (15-64 years) in 2010 reached 66 percent of the total population (around 157 million). The young workers (15-24 years) reached 26.8 percent, or 64 million people. The increase number of productive working age shows the dependency rate, where 100 productive people bear 51 unproductive ones (under 15 and over 64 years).

The demographic transition which is characterized by double increase of the number of productive working age (15-64 years), is accompanied by a delay in the growth of young people (under 15 years), and fewer elderly population (above 64 years) as seen from two results of the census, commonly known as demographic bonus. The demographic bonus is a population ratio that describes an advantage.

Indonesia is expected to receive the demographic bonus around 2020 - 2030. The demographic bonus allows Indonesia to grow into a developed country with high work productivity and economic power that enables it to strengthen its influence at the regional and international levels. Many countries have become rich because they have been able to manage the advantages and opportunity from their demographic bonuses to spur per capita, so that the expected public welfare is achieved, as happened in China, whose economic growth before the demographic bonus ranges from $6 \%$ to $9.2 \%$, South Korea from $7.3 \%$ to $13.2 \%$, Singapore from $8.2 \%$ increased to $13.6 \%$ and Thailand from $6.6 \%$ increased sharply to $15.5 \%$. But the demographic bonus can become a threat if it is not handled properly. It will not provide significant changes if the country has minimal investment in the human resources sector. Therefore, the demographic bonus can also turn into a wave of mass unemployment and increase the burden of national budget.

With the demographic bonus that Indonesia will receive in 2020-2030, the opportunity to achieve high economic growth can be achieved. However, to realize this high level of economic growth, an important aspect that needs to be considered is national strategies in preparing high quality workforces. This quality is related to the quality of education, health, and nutritional adequacy. Education and health, until now, continue to be quite complicated problems, because they are still not evenly distributed throughout the regions of the country. It is shown that there are still many Indonesian people who cannot go to school due to limited school facilities such as accessibility, inappropriate buildings, and lack of teacher professionalism in teaching. In terms of health, there are still many people who experience malnutrition, especially in remote areas. The lack of equal distribution of education and health facilities in the 
remote places in Indonesia causes inequality. Thus, this paper will examine the Contribution of the Quality of the Education System and Health Conditions to Welcome the Demographic Bonus in Indonesia.

\section{DEMOGRAPHIC BONUS PHENOMENA IN INDONESIA}

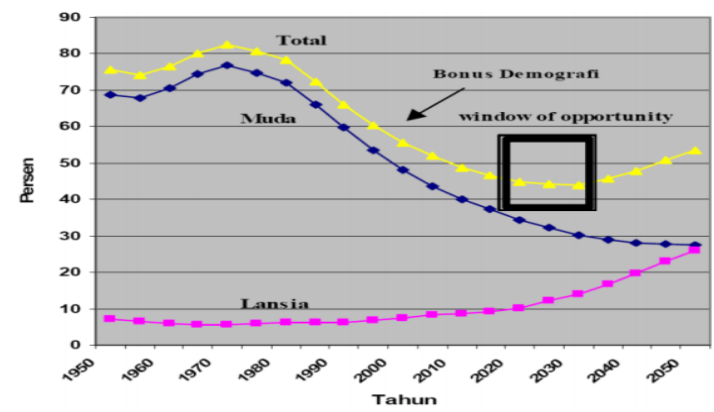

Fig. 1: Level of Emergence of Demographic Bonus in Indonesia. Source: (World Bank: 2011)

Based on the figure 1, since the 1990 to 2000, there was a decrease in the dependency ratio between the young and elderly people, with the range from 10 and 20 million people. The emergence of demographic bonuses has begun to appear since the end of 2000 through the results of the 2000 Population Census. The results of the census provide a clear picture that the family planning program has very positive impacts. As a result, the population under 15 years almost did not increase from the around 60 million in 1970-1980s. Until the end of 2000 , the population was only around 63-65 million. In contrast, the population of 15-64-year old people, which in 1970 was only around 63-65 million, increased to more than 133 - 135 million. The increase is more than twice, or more than $100 \%$ for 30 years. The dependency burden is measured by the ratio of the age population of the children (under 15 years) plus the elderly population (over 65 years) per working age population (15-65 years), has dropped sharply from around 85-90 per 100 in 1970 , to 54-55 per 100 in 2000 . In the 2010 census, the structure of the Indonesian population was dominated by the productive people as described in the following results:

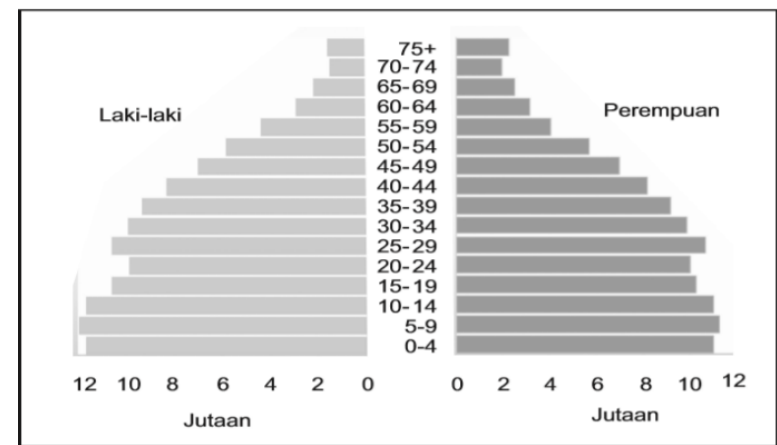

Figure 2: 2010 Population Census.

Source: (BPS, 2013)
In the demographic studies, Indonesia is currently undergoing a demographic bonus period. This is marked by a doubling of the population of productive age accompanied by the delay in the growth of the young age population and the fewer population of the elderly [1]. In other words, this period has decreased the dependency ratio of the Indonesian population.

The demographic bonus has typical economic benefits caused by the decrease in the proportion of young people who reduce the amount of investment costs to fulfill their needs, so that the resources can be transferred to spur the economic growth and improve family welfare. From the results of the 2010 Population Census and Indonesian population projections, there is a dependency ratio as presented in the figure above. In total, the population dependency ratio in Indonesia in 2010 was $50.5 \%$. This means that every 100 people of productive age bear as many as 50-51 people who have not or are no longer productive. The dependency rate is contributed by the youth population dependency ratio of $43 \%$ and the old population dependency ratio of $7.5 \%$. From the composition of the population, in Indonesia in 2010, the ratio between productive age categories was more than double that of the non-productive population age category. From the results of the existing projections, this dependency ratio will continue to decline. The opportunity to get the biggest demographic bonus is on the window of opportunity period that is expected to be reached between 2020 and 2030. In that period, the dependency will have been at its lowest level.

TABLE I. DEPENDENCY RATIO OF INDONESIA AND PROVINCES, 2010-2035

\begin{tabular}{|c|c|c|c|c|c|c|c|}
\hline \multicolumn{2}{|r|}{ Provinsi } & \multicolumn{6}{|c|}{ Tahun } \\
\hline 1 & Aceh & 563 & 2015 & 538 & $\frac{2028}{508}$ & 470 & 458 \\
\hline 2 & Sumatera Utara & 58.0 & $\begin{array}{l}58,6 \\
56.3\end{array}$ & $\begin{array}{l}55,0 \\
55,3\end{array}$ & 53,6 & 51,7 & 50,8 \\
\hline 3 & Sumatera Barat & 57,7 & 55.8 & 54,8 & 53.6 & 51,7 & 50.6 \\
\hline 4 & Risu & 54.1 & 51.5 & 49.7 & 48,4 & 47.1 & 46,6 \\
\hline 5 & Jambi & 50,8 & 47,3 & 44,5 & 43,3 & 42,7 & 42,7 \\
\hline 8 & Sumatera Selatan & 51,3 & 48,7 & 48,4 & 47,3 & 45,8 & 45,3 \\
\hline 7 & Bengkulu & 51,3 & 47,8 & 46,2 & 44,8 & 44,3 & 44,5 \\
\hline 8 & Lampung & 51,1 & 48,5 & 48,6 & 47,3 & 45,6 & 45,3 \\
\hline$\theta$ & Kep. Bangka Belitung & 48.6 & 46.2 & 44.8 & 44,3 & 43,3 & 43,1 \\
\hline 10 & Kepulauan Risu & 46.8 & 49.7 & 46.4 & 41,8 & 38.1 & 37,8 \\
\hline 11 & DKI Jakarta & 37.4 & 39.8 & 42,0 & 42,2 & 40,1 & 38,5 \\
\hline 12 & Jaws Barat & 49.8 & 47,7 & 48,4 & 48,4 & 48,2 & 48,6 \\
\hline 13 & Jawa Tengah & 49.8 & 48,1 & 47,7 & 48,4 & 49,8 & 51,7 \\
\hline 14 & D I Yogyakarta & 45,8 & 44,8 & 45,6 & 46,8 & 47,7 & 48,4 \\
\hline 15 & Jawa Timur & 46.2 & 44.3 & 43,8 & 44,3 & 46,2 & 48,4 \\
\hline 16 & Banten & 48,6 & 46.4 & 45,3 & 43,8 & 41,8 & 41,0 \\
\hline 17 & Bali & 47.3 & 45,6 & 43,3 & 42,2 & 43,3 & 45,8 \\
\hline 18 & NTB & 55.8 & 53.8 & 52,2 & 50,2 & 48,6 & 48,1 \\
\hline 18 & NTT & 70,8 & 68.7 & 63.4 & 62,1 & 61,6 & 81,6 \\
\hline 20 & Kalimantan Barat & 52.7 & 50.8 & 49.7 & 48,8 & 47,3 & 48,6 \\
\hline 21 & Kalimantan Tengah & 50.4 & 46.2 & 43,3 & 41,4 & 40,3 & 38,8 \\
\hline 22 & Kalimantan Selatan & 49,3 & 48.6 & 47,7 & 46,2 & 44,7 & 44,7 \\
\hline 23 & Kalimantan Timur & 48.6 & 46.2 & 44,5 & 43,7 & 43,1 & 43,5 \\
\hline 24 & Sulawesi Utara & 47.8 & 46.6 & 46,4 & 46,8 & 47,3 & 48.4 \\
\hline 25 & Sulawesi Tenggh & 52.7 & 50.6 & 49.7 & 49,5 & 48,6 & 48,6 \\
\hline 28 & Sulawesi Selatan & 56.0 & 52,8 & 51,3 & 50,4 & 49,5 & 49.7 \\
\hline 27 & Sulawesi Tenggara & 63.4 & 60.5 & 58,0 & 54,8 & 52,7 & 51,5 \\
\hline 28 & Gorontalo & 51.7 & 48.6 & 47,5 & 47,7 & 47,7 & 47,8 \\
\hline 28 & Sulawesi Barat & 60.5 & 56.0 & 53,8 & 52,7 & 51,5 & 51,1 \\
\hline 30 & Maluku & 63.1 & 59.7 & 58.2 & 57,5 & 55,8 & 54,3 \\
\hline & Maluku Utara & 61,3 & 58.5 & 58,0 & 53,4 & 51,5 & 50,8 \\
\hline 32 & Papus Barat & 53.6 & 49,8 & 47,1 & 45,3 & 44,3 & 43,7 \\
\hline & Papua & 53.8 & 47.5 & 43,7 & 42,0 & 41,6 & 42,2 \\
\hline & lonesia & 50,5 & 48,6 & 47,7 & 47,2 & 46,9 & 47,3 \\
\hline
\end{tabular}

Source: Indonesian population projection 2010-2035 
Based on the table 1 , in 2015, the national dependency ratio was 48.6. If referring to the data from Indonesian population projections, by 2025, Indonesia will reach the window of opportunity. Based on population projection data per province, this window of opportunity will not be experienced simultaneously by all provinces in Indonesia. There are some that experience the opportunity faster than others. However, there are also some that are projected not to experience it even though after 2035.

Most provinces in Indonesia have entered the demographic bonus period in 2010. From the table above, there are 12 provinces that have entered the window of opportunity. In 2015, there were 9 provinces that had entered the window of opportunity. Then, in 2020, there are 3 Provinces which are predicted to enter the window of opportunity, namely Riau, West Kalimantan and Central Sulawesi. Meanwhile, the Provinces of Nanggroe Aceh Darussalam, West Nusa Tenggara and South Sulawesi are predicted to enter this period in 2030 . In addition, there are 7 provinces, namely North Sumatra, West Sumatra, NTT, Southeast Sulawesi, West Sulawesi, Maluku, and North Maluku, which are predicted will not enter the window of opportunity before 2035 .

According to the Head of the Demographic Institute of Faculty of Economics of Universitas Indonesia, Dr. Sonny Harry B. Harmadi, it is estimated that Special Region of Jakarta, Batam City, and Surabaya City will experience the window of opportunity for many times. This may be possible because the three regions have a very strong appeal which causes many young people to come to seek for livelihood in these cities. Then, many of them will return to their villages before their retirement age.

Even though in the demographic transition period, especially when the window of opportunity is opened, there is also a great opportunity to get the demographic bonus. But, as stated earlier, that demographic bonus does not automatically occur. Bloom et al., Ross, and Adioetomo suggest that there are at least three main channels of influence of the demographic transition toward the economic growth, namely by increasing the number of labors, national savings, and human capital [1, 4, 14]. To fulfil these three transition effects, there are several supporting factors; one of them is the investment in improving access and quality of education and health. These policies will be related to the effectiveness of the formation of human capital and success in preparing quality labors, not only high in number but also more productive.

Thus, there should be still many efforts to realize the window of opportunity and gain demographic bonus in Indonesia. The government's efforts through various policies and programs are needed, not only at the central level, but also at the local government.

\section{QUALITY OF EDUCATION SYSTEM TO WELCOME THE DEMOGRAPHIC BONUS}

One important aspect that needs to be considered in utilizing demographic bonus is by strengthening the needs for quality education. The increasing number of young people in 2020 to 2030 influences the increasing needs for educational facilities. With the easy opportunity to get educational services, it can certainly create qualified and skilled human resources. To improve the quality of young people as future productive populations, one of the efforts that can be done is to provide the educational opportunity as wide as possible. Ease of access to education and supported by adequate education infrastructure, as well as qualified educators, will create a quality society as well. With the opportunity to get education to the highest level, it will certainly be an important capital to create quality and skilled workforces.

The World Bank states that the quality of education in Indonesia is still low, although the expansion of accessibility toward the education for the community has improved significantly. The quality of education is reflected in the number of illiterate people. $55 \%$ of 15 -year old in Indonesia are functionally illiterate, compared to Vietnam which is less than $10 \%$. On the other hand, the number of students who are now able to attend school has increased too. This increase can be seen in the form of financing, educational facilities, and teachers' quality. Improving the quality of education is a major factor in the success of employment planning. The workforces planning will guarantee the needs of the workforces, especially educated workers needed in the development process [15]. In the framework of demographic bonus, the employment planning is closely related to the development of human resources quality.

Looking at the School Participation Rate (APS) in Indonesia, it is shown that there is an increase in APS in each group of age from 2007 to 2017.

TABLE II. THE SCHOOL PARTICIPATION RATE ACCORDING TO THE AGE

\begin{tabular}{|c|c|c|c|c|c|c|c|c|c|c|c|}
\hline \multirow{2}{*}{$\begin{array}{c}\text { Kelompolk } \\
\text { Umuut }\end{array}$} & \multicolumn{10}{|c|}{ Tahum } \\
\cline { 2 - 13 } & 2007 & 2008 & 2009 & 2010 & 2011 & 2012 & 2013 & 2014 & 2015 & 2016 & 2017 \\
\hline \hline $7-12$ & 97.39 & 97.60 & 97.83 & 97.95 & 97.97 & 97.53 & 97.94 & 98.34 & 98.83 & 98.59 & 98.98 \\
\hline $13-15$ & 84.08 & 84.26 & 84.41 & 85.43 & 86.11 & 87.79 & 89.61 & 90.62 & 94.32 & 94.59 & 94.79 \\
\hline $16-18$ & 53.92 & 54.61 & 54.70 & 55.05 & 55.83 & 57.69 & 61.30 & 63.64 & 70.13 & 70.32 & 70.68 \\
\hline $19-24$ & 11.38 & 12.20 & 12.43 & 12.66 & 13.67 & 14.47 & 15.94 & 20.04 & 22.74 & 22.79 & 23.80 \\
\hline
\end{tabular}

The increase in APS in each of these age groups can be influenced by the increase of the need for education when the number population is also getting 
higher. The increase of APS shows something good viewed separately in each age group. However, if the School Participation Rate is compared with the age group, it still shows very unbalanced figures.

The trends in School Participation Rate that are getting smaller on high age groups are quite worrying problems. The smaller the School Participation Rate in the high age group, the population which has been succeeds in the higher education is also still relatively small. The relatively small school participation rate in the 19-24-year age group can be influenced by several factors such as: poverty, expensive educational costs, low school motivation at higher educational level, and so on.

In the bonus demographic phase, the School Participation Rate must be increased, especially the School Participation Rate in the 16-18- and 19-24year age groups. One step that can be taken is to provide the opportunity for having education as wide a possible. With cheap education and educational assistance for the poor, it can spur the increase of the school participation rate. The high school participation rate in the 19-24 age group will create a quality and skilled workforce. A high level of education is the main provision to face workforce's competition.

The main factor to improve the quality of education lies in the availability of complete and adequate educational facilities and infrastructure, including access to the schools. Besides, adequate and qualified number of educators is also one of the important aspects that cannot be ignored. The government must also pay attention to the development in the field of science and technology supporting education. Only by increasing and improving the important elements of education will be the main key to improving the quality of education.

However, it cannot be denied that formal education is not the only the determinant of success in creating quality workforces. Therefore, the government must also seek and develop non-diploma education that emphasizes the skills development. The development of skills through non-formal education can be an alternative to create high quality workforces. Non-diploma education can be a solution to cover the limitations of formal one and is appropriate for accommodating young people who do not fit into the more formal education.

In addition, education is also expected to improve the quality and morals of the nation, especially the youth. With the rolling out of character-building education proclaimed by the government, it is expected that the world of education will generate human beings with noble characters as well as achieve the goals of Indonesian national education. In this case, the synergy among the three pillars of education is needed, namely schools, parents and the school community if it is understood as a "workshop" for students who can solve their problems. It is not completely wrong because schools are places for educated teachers. However, indirectly, this understanding reduces the role of the family in educating the students, even though we understand that family is "the first school of students". In this case, it needs to be understood together that parents cannot fully impose the obligation to educate students to the teachers as schools without any effort to get involved in their own children education. The schoolcommunity relation is to increase involvement, care and support from the community, both morally and financially.

\section{HEALTHY CONDITION TO WELCOME THE DEMOGRAPHIC BONUS}

Today's health development greatly determines our success in utilizing demographic bonus optimally. Various health development programs that have been pursued and implemented by the Ministry of Health today are expected to contribute positively toward the efforts to optimize the upcoming demographic bonus period. According to Law Number 36 of 2009 on the Health in Chapter I Article 1, it is explained that health is a healthy condition, both physically, mentally, spiritually and socially, which allows each person to live productively, socially and economically.

The quality of health is an important aspect that needs to be improved to welcome the demographic bonus. The realization of a healthy family should be supported by adequate nutrition, so it will provide a solid foundation for the realization of the quality of human resources that can answer the challenges in this rare demographic period. Healthy families with good nutrition play an important role, because they function as a foundation for the achievement of other developmental goals. Improving the quality of health will also improve the workforces in educational aspect. Providing good and quality health services will be the key to improve the quality of people's health.

The development in the health sector aims at making all levels of society obtain health services easily, cheaply and evenly. Through this effort, it is expected that better level of public health will be achieved. Various efforts to improve public health status have been carried out by the government so far. Health is also one aspect that can be used to see the welfare of a nation. There are three indicators in health that are commonly used to see the level of 
welfare, namely Infant Mortality Rate (IMR), Life Expectancy Rate, and Illness Rate (BPS).

Besides the three indicators above, there are other measures to see the level of health, including the percentage of people visiting various public facilities such as health centers, village medicine posts, village maternity huts, clean water facilities, and the percentage of community involvement in healthy living behavior.

Improved health status is expected to improve the productivity of the population to achieve national prosperity. Indan argued that health is one of the most crucial aspects in building the human elements to have the expected quality, able to compete in this era with full of challenges, now and in the future [16]. The absence of a sick person means that there is no community burden and removal of the source of disease transmission. Healthy people, besides being able to take care of their own needs, are also beneficial for the community, because they can contribute their energy and thoughts in the development of the nation and state.

Without healthy individuals with enough nutrition, we cannot achieve high levels of education. Healthy families with adequate nutrition are pre-conditions to achieve other development goals, because it is impossible for us to realize competitive human resources without having this basic requirement.

\section{OPPORTUNITY AND THREATS OF DEMOGRAPHIC}

For Indonesia itself, demographic bonus can be a great opportunity for to conduct development in various aspects. Currently, the Indonesian people are dominated by the population of productive age. Therefore, in the next few years, Indonesia will not experience the lack of quality human resources that can build the nation. Another opportunity is the demographic bonus results in reduced economic burden that must be borne by the population of productive age. There is a decrease in the level of dependence of non-productive age people on the productive one. Economic growth that is well managed by our human resources will lead to development progress and prosperity for all Indonesian people. Wasisto Raharjo Jati stated that the demographic bonus will provide economic benefits if it meets the following requirements: good supply of labors, thereby increasing per capita income if they get productive employment opportunities; the role of women, where the small number of children allows women to enter the labor market and can help to increase the family income; community savings that are invested productively; and quality human capital [9].
The demographic bonuses must be optimized to the maximum extent for economic growth through investment in modern human resources. To be able to take advantages of the demographic bonus, Indonesia must get prepared well and meet the criteria described above. Viewed from the macro picture of Indonesia's development process, there is still an imbalance between western and eastern regions of Indonesia. This can be seen from the Gini Index, which is an indicator to measure inequality in development and income. Based on BPS data, in March 2018, the level of inequality in Indonesia's population expenditure as measured by the Gini Ratio is 0.389 , meaning that the level of inequality is low. This figure has decreased by 0.002 points compared to September 2017's Gini Ratio of 0.391. Meanwhile, compared to March 2017, the Gini Ratio of 0.393 has dropped to 0.004 points. Meanwhile, the Gini Ratio in urban areas in March 2018 is recorded down by 0.404, compared to September 2017's Gini Ratio of 0.404 and March 2017's Gini Ratio of 0.407. Meanwhile, Gini Ratio in rural areas in March 2018 was recorded at 0.324, up by 0.004 points compared to Gini Ratio in March 2017 and September 2017 which was 0.320.

The government must seriously work on the human resources in Indonesia so that they can use this demographic bonus wisely. In addition to the Gini ratio, inequality can also be seen from the Human Development Index (HDI). The HDI reflects the quality of health (life expectancy at birth), education (duration of school attendance) and the economics aspect (per capita income) of a country. Based on the BPS data in 2018, the value of HDI in 2017 reached 70.81 ; it is in high category, increased by 0.63 points from 2016. The increase in the Human Development Index (HDI) in 2017 has had a good impact on the quality of education, health and life needs.

The demographic bonus will just pass if Indonesian society does not have the efforts to utilize it. This is what has become an irony in our country, that this great potential is not being addressed well. This is compounded by high rate of childbirth, maternal mortality and early childhood deaths, drug abuse, unhealthy living habits, damage to the social environment and morals, as well as high rate of unemployment, and criminal acts. If these problems are not addressed and resolved properly and comprehensively, Indonesia can fall into a failed state.

\section{CONCLUSION}

Demographic bonus is a population ratio that describes an advantage. This factor is caused by a comparison of the number of non-productive age population (less than 15 years and more than 64 years) less than the productive population. This 
phenomenon occurs because the process of demographic transition over the past few years in Indonesia will open opportunities to enjoy demographic bonuses. Indonesia is expected to receive a demographic bonus around 2020 - 2030. But demographic bonuses can become a threat if not handled properly. Demographic bonuses will not provide significant results if the country has minimal investment in human resources. Some of the determinants of the successful use of demographic bonuses include increasing the quality of education and health conditions.

To improve the quality of young people as future productive populations, one of the efforts that can be done is to provide the widest possible educational opportunity. Ease of access to education and supported by a complete education infrastructure, as well as qualified educators, will create a quality society as well. Quality of health is an important aspect that needs to be improved to welcome the demographic bonus. The realization of a healthy family is supported by adequate nutrition, so it will provide a solid foundation for the realization of the quality of human resources that can answer the challenges in this rare demographic period.

\section{REFERENCE}

[1] Adioetomo, Sri Moetiningsih Setyo, "Bonus Demografi Menjelaskan Hubungan Antara Pertumbuhan Penduduk dengan Pertumbuhan Ekonomi”, Pidato Pengukuhan Guru Besar Tetap Dalam Bidang Ekonomi Kependudukan Pada Fakultas Ekonomi Universitas Indonesia, 2005.

[2] Badan Kependudukan dan Keluarga Berencana Nasional. Bonus Demografi, Meningkatkan Kualitas Penduduka Melalui Keluarga, $2017 . \quad$ Retrieved: http://www.bkkbn.go.id/detailpost/bonus-demografimeningkatkan-kualitas-penduduk-melalui-keluarga.

[3] Bank World, Indonesia's Intergovernmental Transfer Response on Future Demographic and Urbanization Shifts. The World Bank, 2011.

[4] Bloom, D.E., D. Canning, J. Sevilla. The Demographic Dividend, A New Perspective on the Economic Consequences of Population Change. Santa Monica, California: RAND, 2003.

[5] BPS. Proyeksi Penduduk Indonesia 2010-2035. Jakarta, 2013.

[6] Indeks Pembangunan Manusia (IPM) Tahun 2017, 2018

https://www.bps.go.id/pressrelease/2018/04/16/1535/indekspembangunan-manusia--ipm--indonesia-pada-tahun-2017mencapai-70-81--kualitas-kesehatan--pendidikan--danpemenuhan-kebutuhan-hidup-masyarakat-indonesiamengalami-peningkatan.html.

[7] _. Tingkat Ketimpangan Pengeluaran Penduduk Indonesia Maret 2018.2 Retrieved: https://www.bps.go.id/pressrelease/2018/07/16/1533/giniratio-maret-2018-tercatat-sebesar-0-389.html.

[8] Fauzie, Y.Y, Bank Dunia: Kualitas Pendidikan Indonesia Masih Rendah, CNN Indonesia, 2018. Retrieved: https://www.cnnindonesia.com/gayahidup/20180607113429-284-304214/bank-dunia-kualitaspendidikan-indonesia-masih-rendah//.
[9] Jati, Wasito R. 2014. "Bonus Demografi Sebagai Mesin Pertumbuhan Ekonomi: Jendela Peluang atau Jendela Bencana di Indonesia". Jurnal Populasi Vol. 25 No.1, Yogyakarta: Pusat Studi Kependudukan dan Kebijakan. 2015, pp. 1-19.

[10] Kementerian Riset, Teknologi dan Pendidikan Tinggi. Mengoptimalkan Bons Demografii, 2017. Retrieved: https://ristekdikti.go.id/info-iptek-dikti/mengoptimalkanbonus-demografi/.

[11] Kementerian Kesehatan Republik Indonesia. Bonus Demografi dan Investasi pada Pembangunan Kesehatan dan Gizi, $2016 . \quad$ Retrieved: http://www.depkes.go.id/article/view/16102800001/bonusdemografi-dan-investasi-pada-pembangunan-kesehatan-dangizi-.html.

[12] Umar, Muhammad Agus. Bonus Demografi Sebagai Peluang dan Tantangan Pengelolaan Sumber Daya Alam di Era Otonomi Daerah. Jurnal Genta Mulia. Volume VIII No. 2, 2017. Pp. 90-99.

[13] Undang-Undang Nomor 36 Tahun 2009 tentang kesehatan, 2009.

[14] Ross, J., "Understanding the Demographic Dividend". Mimeograph. Washingtoon: The Policy Project, Futures Group, 2004

[15] Sumarsono, Sony. Ekonomi Manajemen Sumber Daya Manusia dan Ketenagakerjaan. Yogyakarta: Graha Ilmu, 2003.

[16] Win Konadi dan Zainuddin Iba. Bonus Demografi Modal Membangun Bangsa yang Sehat dan Bermartabat. Jurnal Variasi. Volume 2 No. 6, 2011, pp. 18-23. 